Toward the decolonisation of religion education in a pre-service education classroom

Omar Esau

Oesau@sun.ac.za

Faculty of Education, Stellenbosch University, Stellenbosch, South Africa 


\title{
Toward the decolonisation of religion education in a pre-service education classroom
}

\begin{abstract}
In this article I reflect on my attempts to decolonise religious education at a historically white university in a post-apartheid South Africa. This pre-service education project conducted in 2017 happened against the backdrop of two events, namely, a renewed curriculum policy, Curriculum Assessment Policy Statement (CAPS) and the \#RhodesMustFall (RMF) and \#FeesMustFall (FMF) protests. These events encouraged me to reflect on my academic role as a teacher educator preparing pre-service teachers to teach religion in schools. This led to me asking many questions such as, what is the effect of my teaching religious education?, How do teacher-educators prepare religious education pre-service teachers for a multicultural and multireligious society?, How does my teaching align itself with the decolonisation of education? and How do I redress the colonial past in my religious education classroom?
\end{abstract}

The data which included reflective reports, student experiences and self-reflexivity acknowledged the findings that religion education served as a unifying factor in building social cohesion. The significance of this paper lies in the argument that decolonisation becomes an imperative if one is striving for social justice and intends to commit oneself to a more equitable society where crossing borders must be a seamless act.

Keywords decolonisation; decolonial project; religious education; pre-service teachers

\section{Introduction}

The \#RhodesMustFall and \#FeesMustFall student revolts and uprisings which started in late 2015 unleashed student power reminiscent of the 1976 student revolts. These student protests have been the impetus for a renewed interest in decolonisation or decoloniality (Le Grange 2016). In the context of these events, I ask, "how do I go about decolonising my religious education classroom?"

In this paper, I give a brief historical background of the curriculum policy change in religious education in South Africa and the challenges facing the teaching of religious education in schools or in pre-service teacher education today amidst the underlying decolonisation outcry. I reflect on my role as a lecturer in a pre-service teacher's classroom aiming to analyse how my teaching as a religion education lecturer contributes to the decolonial project. I see myself as a religion education lecturer instead of a religious education lecturer and argue why this latest student campaign was and is so important in the quest for a more liberated and decolonised society.

The term decolonialisation tends to be a buzzword and as a contemporary teacher-educator, the concept questioned my way of thinking about the way I was teaching about religion. The main question I set out to answer in this paper is: How can the teaching about religion encourage social cohesion, promote diversity and inclusivity and contribute to decolonisation?

\section{What then is decolonisation?}


The Cambridge dictionary calls decolonisation "the process in which a country that was previously a colony controlled by another country becomes politically independent". Much has been written about decolonisation and what it entails by writers such as Nelson Maldonado-Torres (2007, 2016), Walter D. Mignolo (2011), Achille Mbembe (2001) and Santos de Sousa (2016). Instead of going into the detail of the various descriptions of decolonisation I rather focus on 'doing decolonisation'. I actively engage in addressing and redressing colonial inequalities. Decolonisation is not an imposition, but a becoming. This process of becoming and unfolding does not necessarily mean destroying Western knowledge but rather decentring it or perhaps deterritorialising it and making it something other than what it is (Le Grange 2016). Smith (1999) identified the following elements of decolonisation: deconstruction and reconstruction; self-determination and social justice; ethics, language, internationalisation of indigenous experiences, history and critique. In his deliberation regarding indigenous scholars and decolonisation Le Grange (2016) also establishes five phases in the process of decolonisation: rediscovery and recovery; mourning; dreaming; commitment and action. Action is the phase where dreams and commitments translate into strategies for social transformation. While decolonising the curriculum can mean different things for various change agents, it includes a fundamental reconsideration of who is teaching, what the subject matter is and how it's being taught.

\section{The decolonisation of religious education?}

It is true that education over the years in South Africa had been used to promote and strengthen the norms and the values of the white colonists. Prior to 1994, the South African education system was organised along racial lines based on the Christian National Education (CNE) ideology of no mixing of languages, cultures, religions and races. It was within this context of CNE policy that Fundamental Pedagogics emerged. According to Enslin $(1984,146)$, Fundamental Pedagogics was an instrument to justify the South African Government's position regarding apartheid and education. This was a compulsory subject for any pre-service teacher who intended to teach in South Africa prior to the capitulation of the then apartheid state.

Under the apartheid regime, with its commitment to Christian National Education, a narrow set of religious interests captured religious education. Although all education was supposed to inculcate a Christian national ethos, religious education, assuming a Christian, Bible-based character, sought to produce distinctively religious outcomes. Religious education was driven by a particular kind of Christian confessionalism and triumphalism, a confessionalism that required pupils to embrace prescribed religious convictions and a triumphalism that explicitly denigrated adherents of other religions (Chidester 2002).

In South Africa with the advent of the new curriculum, Curriculum 2005 and now (Curriculum Assessment Policy Statement) CAPS since 2012, the topic of religion is often found in the Life Orientation/Life Skills curriculum as part of the study of cultures, holidays and celebrations around the world. Educators refrain from sharing their own beliefs, but learners may share their religious perspectives and asks questions. Different religious interests, therefore, have surfaced in the controversy over the new policy for religion education. Although "concerned Christians" have spoken against the policy, religious leaders from a variety of religious 
communities have supported this new initiative. In public education, as Father Albert Nolan has argued, "the school is not responsible for nurturing the religious development of the scholars but for providing learners with the knowledge about religion and morality and values and the diversity of religions" (Nolan 2001). Representing the Muslim Judicial Council, Sheikh Achmat Sedick has observed that there is no problem with religion education "as long as it is orientation and not indoctrination" (Sunday Times 28 October 2001). Other religious leaders have indicated their support for teaching and learning about religion. Thus, the new policy insists, the role of religion in the schools must be consistent with constitutional provisions for freedom of religious and other beliefs and freedom from religious and other discrimination.

It is obvious that there are many concerns surrounding the teaching of religious and spiritual diversity in public schools. These concerns fall under the categories of constitutionality, controversy, content expertise, and curricular constraints.

The first concern as already pointed out above was constitutional. In the new South African constitution of 1996, the Bill of Rights emphasized freedom of religion, so teaching about religion and not promoting a specific religion was strongly advocated. It was within this constitutional framework, trained educators rather than religious leaders, clergy, or the old regime's "devout teachers" lead in developing resources for teaching and learning about religion, religions, and religious diversity.

The second concern is that teaching about religion is too controversial. Teachers, principals, and school governing bodies fear that parents or community members will object to religion in the curriculum. Some teachers consider teaching about religion even more controversial than sex education (Kilman 2007). A related controversy is that some educators may misuse their positions of authority, intentionally or unintentionally, to promote their own religion. The teaching of evolution is one example in which some teachers and school officials mistakenly believe that teaching about evolution, a requirement in the science curriculum, negates the Biblical story of creation (Brooke 2010). Even teachers who honour the multiplicity of cultural backgrounds within schools and communities may experience conflict between what their faith expects of them and their belief in the separation of church and state (Oldendorf and Green 2005). Fortunately, many teachers have, either through in-service courses or their own study, become knowledgeable of constitutionality and necessity of the "civic public school" which promotes objective teaching about religion without promoting or denigrating it (Prothero 2007). Yet many find it confusing when they have to select the content for a curriculum on religious diversity. As a result, some teachers choose not to bring up religion at all.

The third issue is the lack of preparation that many public-school educators have for teaching about religious and faith diversity. Although most educators respect the diverse religious traditions of their learners, they often do not know much about those traditions. Although innovative textbooks to explore religious diversity (Amin, et al. 1998), religious festivals (Stonier, et al. 1996), sacred places (Stonier and Derrick 1997), and African indigenous religious heritage (Kwenda, et al. 1997) have been developed, much is needed to make the teaching of religion education more inclusive. 
A final concern, due in part to the new curriculum, is that life orientation has become a marginalised subject. Since life orientation is the most common 'home' for teaching about religion, and since it has been marginalised by high stakes testing in math, reading and writing, it is an uphill struggle to include religion in the curriculum. Introducing the study of a "new" subject, such as religion, is far down the list of priorities in most public schools. However, omission of the topic of religion leaves students unable to understand current world conflicts or even the basis of certain disagreements within their own country. Outside of faith settings, contemporary religious education is invariably defined by a separation of religious education from the religious life. The problem of modern religious education remains, how to ground the subject when it is no longer grounded in the religious life (Gearon 2014).

Given the demands on the curriculum, the best we can hope for is that the school can provide learners with a basic introduction to religion, religions, and religious diversity in ways that might increase understanding, reduce prejudice, and facilitate respect. Since democracy rests on the need for educated citizens, religion as a topic should be included in the school curriculum to help students better understand the past and the present, to understand human motivations, and to develop empathy for people who live in other places and have a different worldview. According to Martin Marty $(2000,66)$, religion is too important an aspect of human existence, to be left out of public education. This view is further enhanced recently by Eva Reimers (2019) when she researched secularism and religious traditions in nonconfessional Swedish preschools, in order to pass on a relevant and more authentic cultural heritage to the children in a multicultural and multireligious society, they need to bring more religion, and more religions, into the preschools.

\section{Teaching Religion Education as part of the Decolonial Project?}

Within this context, I now find myself teaching a module on Religion Education in a pre-service teacher education program at a previously White University which had a strong Christian ethos. The challenge I have is to teach this compulsory module that remains a very sensitive subject. As a lecturer coming from a faith-based school I somehow felt confident enough that I had a nuanced understanding of how students perceived the idea of learning and being exposed to other religions. In a post-apartheid era, the school and the university face the challenge of becoming more inclusive of the South African 'Rainbow Nation'. Banks (2006, 208) observed that 'unity without diversity results in hegemony and oppression; diversity without unity leads to Balkanization and the fracturing of the nation-state'. This fits with my own values and experience. As a teacher educator I must prepare future teachers to go out and work with learners from diverse socio-economic, race, gender, language and cultural backgrounds. Within the faculty where I teach, I must encourage conservative white students to teach in a township and not to see it as a 'no go zone'.

Religion is inherently and universally part of our humanness. In my Religion Education teaching plan, I focus on the diverse religions including Christianity, Islam, Judaism, Buddhism, Hinduism and African Traditional Religion. The aim is to develop an appreciation for the rich diversity of people of differing faiths and religion. The answer lies in embracing religious pluralism, a concept that can help educators see ways to respect and honour the full spectrum 
of religion and spirituality without giving preference to any one tradition. I therefore set out to expose the students to the various religions as a part of my planned decolonial project.

Given the centrality of racial discrimination to the apartheid era, my decolonial project inevitably refers particularly to eradicate racism, xenophobia, sexism, religious intolerance and other forms of inequalities found within society in a classroom. Apartheid was merely a continuation and a strong form of colonisation and high on my agenda as a social justice teacher educator I had to dismantle or decolonise it. Apartheid traumatised and impacted on people's culture and identity. In my classroom I had to nurture, support, and affirm the identities of all the students, not only to confront the apartheid mindset but to encourage a new path, one that endorse national values, become cosmopolitans, and work to make both the local and the global a more humane and just place for all. When we share knowledge, we are decolonising and moving towards new frontiers. Sharing spaces and sharing knowledge about the other religion is part of decolonising.

Decolonising religious education in a previously Christian biased institutional environment is not without its own challenges. In the decolonial project it is imperative that as an individual, I move from favouring one religion above another and giving preference to any one tradition.

In my decolonial project I explain how my religion education classroom activity in a preservice education program attempts to address religious diversity and I also expound on the obstacles that hinder the development of new models and strategies to support religious diversity in the classroom and the greater society.

\section{Teaching religious diversity for social cohesion as a decolonising action in a pre-service teacher programme}

This project (2017) was a social cohesion initiative as part of a decolonisation process to prepare pre-service teachers to teach religious and spiritual diversity in public schools. I was interested in creating a better understanding amongst my students regarding the beliefs and spiritual traditions of religions other than their own. Based on qualitative approaches we, as a class, researched religious and spiritual traditions by consulting various religious scholars, religious practitioners, visiting various religious services, religious schools and engage in practice teaching religious lessons. This decolonial project was all about students gathering and disseminating knowledge about religions other than their own.

Schools in South Africa today, welcome children from many countries and cultures, who bring with them diverse languages and dialects, traditions, and beliefs. As teachers make the connection with the world's children in their classrooms, they need to be aware of the spiritual and religious faiths and practices of their learners and families. It was the contention of this study that an investment in religion education at a pre-service level can be fundamental in promoting social cohesive classrooms, lecture theatres and communities in South Africa. This has become a major challenge in South Africa with the recent spate of xenophobic attacks, misconceptions and continuing racist and religious intolerances. In this decolonising study I focused on my attempts to inculcate and enhance religious diversity for social cohesion in my Bachelor of Education classroom. Children bring to school not only their cognitive, physical, and emotional differences, but also their cultural traditions including 
religious practices. When teachers have learners in their classrooms who are Muslim, Hindu, Buddhist, Jewish or Christian, they have a vested interest in learning about their learners' religious beliefs and practices. If learners are to feel accepted at a school, teachers will need to demonstrate that they respect their deepest beliefs and convictions. Teachers and students need to move beyond the idea of tolerance to an "active attempt to understand the other" (Eck 2001, 70). This was also encouraged by Tünde Puskás and Anita Andersson (2019, 398) for teaching about and teaching from religion in Sweden. Their way of working with the religious and secular narratives that surround Easter constitutes an example of the fruitfulness of worldview sensitivity, that is the ability to work inclusively with both religious and nonreligious worldviews, for teaching about and teaching from religion.

Teacher educators have a responsibility to prepare pre-service teachers to become religious diversity sensitive educators. Pre-service teacher preparation in religious sensitive and peace education is critical because teachers are important contributors to educational policy and moreover, they are responsible for the practical implementation of education in the schools. While there is no consensus definition of religious diversity for social cohesion, in this study it is taken to mean a comprehensive system that equips pre-service teachers and learners with requisite skills to resolve conflicts non-violently and create a culture of peace.

\section{Context of the Study}

During the academic year of 2017 I engaged the prospective teachers in a compulsory group work research project as an assignment in the religious education module in the Bachelor of Education course in the Faculty of Education at the University of Stellenbosch. One hundred and six students registered for the module and the class was divided into groups of 6-8 students for the group projects. The majority of the PSTs were white middle-class Christian students with a minority of black students, some coming from poor and non-Christian backgrounds.

\section{Negotiations and Ethical Considerations}

Before I commenced with my project, I felt that it would be ethical to discuss my work with the students and negotiate around this with the various participants involved in my research project. As Ely $(1999,218)$ points out: "Qualitative research is an ethical endeavour." I could not possibly claim to be empowering the students if I did not involve them at the start of the research process. Whilst ethics can be viewed as requiring ethical behaviour towards the participants in my project, it also commits us to mutual respect and not to do harm (Whitehead and McNiff, 2006). To participate in this study, all participants were asked to give their informed consent. Apart from having the option of opting out at any time, the participants were assured of anonymity in my report on this study.

\section{Methodology and Data Collection}

The main question I set out to answer in this paper is: How can the teaching of religion encourage social cohesion, promote diversity and inclusivity and contribute to decolonisation? 
The focus of this study was the preparation of pre-service teachers in religion education and to expose them to an effective approach for building durable peace, respecting diversity and social cohesion in South Africa. In sharing their lessons and views they were enhancing not only the prospect of a better world class citizen, but they were also dismantling the colonial mindset and 'doing decolonisation'.

The research methods utilized are qualitative and interpretive. Interpretivism aims to move away from obtaining knowledge through experimental manipulation of human subjects, towards understanding by means of conversations with subjects (Guba and Lincoln 2005). Social reality is viewed as socially constructed based on a constant process of interpretation and reinterpretation of the internal, meaningful behaviour of people (Denzin and Lincoln 2000). The data techniques used in the study (February 2017-September 2017) were mainly student reports, discussions and interviews. Students were given assignments to present and discuss various religions and its understanding concerning religious diversity for social cohesion. They were also prompted to address how their project could add value to decolonisation?

\section{Findings, discussions and limitations}

The findings of the study gave an overall perspective of the developmental needs of preservice teachers (PSTs) who are acquiring religious diversity skills in South Africa in a volatile era where decolonisation was a buzzword. When first confronted with the research project, most of the PSTs appeared rather apprehensive about tackling the task. We first had to unpack the concepts of decolonisation, social diversity, social cohesion and cosmopolitanism. The PSTs in their assigned groups had to visit, observe and interact with religious centres that they were not familiar with. This was taking them outside of their familiar surroundings and the comfort of the classroom. After making their initial contact, most of them became more enthusiastic and saw the benefit of moving outside the university environment. Overall, the PSTs reported that it was indeed worthwhile to learn about multicultural, multi-religious issues and diversity and inclusivity. Through multicultural and multi-religious education, one begins to see the perspectives of the other and start respecting and accepting differences.

The themes that emerged from the analysis of the data related to students' individual reactions, perceptions and experiences in relation to their research, projects, site visitations, practice teaching, interaction and engagement with others, as well as to the factors that inhibit or aid the enhancement of critical multicultural literacy. Three themes in particular emerged from the analysis of the data.

First, the pre-service teachers were able to engage with other cultural and religious groups and co-construct knowledge with their peers. I was impressed and intrigued by the diversity and the scope of the research questions that the students formulated. At the end of the final semester students wrote their final papers on their journey of learning about their assigned cultural group project. Most of the students felt that their research projects made them more socially responsive to social justice issues. Some of them never realised how other religions and cultures were being side-lined or merely disregarded. Thus, exposing pre-service teachers critically to multicultural literacies develops and nurtures much needed social consciousness 
and social justice in future educators. Most students found the process to be helpful and planned to do critical multicultural and multireligious programmes in their future classrooms and immediate communities.

Below are some comments (18 October 2017) that illuminate critical multicultural literacies among the student teachers. I believe that these comments strongly suggest that the project did indeed develop and enhance cultural awareness and sensitivity amongst the PSTs:

This project definitely made me aware of the importance of human rights. In my project I focussed on Religious Beliefs and Freedom of Speech. This, I believe is the cornerstones of being a human being.

There are different religious beliefs and other cultures, and one must respect the religious beliefs of others. Respecting other religions and their belief systems strengthens one's own belief as well. Being tolerant (for want of a better word) of any other religious belief besides your own makes you a more "rounded" human being.

Freedom of speech is the essence of democracy. Once your voice is taken away from you, then your human rights also disappears. After interviewing a Muslim woman about Islam, I received another perspective. Looking at our country, South Africa's constitution is amongst the most democratic constitutions in the world. Trying to live according to our constitution remains the ultimate challenge to us all.

Second, pre-service teachers' projects focused on meeting the teaching and learning needs of all the learners in their respective classrooms. The student teachers used this class assignment to inform their teaching practices in particular classroom situations during school teaching practice, which they found culturally challenging to address. Most student teachers reflected on how they were able to understand their teaching practices more fully by engaging in this project. Each of the student teachers recognised the potential of using their new literacy skills as a means of exploring how to improve their teaching practice based on the particular contexts and needs of their learners. One student emphasises how her religious diversity \& inclusivity project impacted on her practice teaching:

When I visited the mosque during my project, I realised the importance of wearing the head scarf for Muslims, I could understand why it was important for these learners to wear scarfs in my classroom during my practice teaching.

The Third theme was about pre-service teachers of colour who went to do their practice teaching at previously white only schools that they did not historically attend. They were doing boundary crossing. These PST's felt that during their practice teaching they experienced some evidence of racism and that the process of decolonisation is a journey still very much to be undertaken. Although these elite previously white schools, forefronts multicultural and multireligious policies, in practice subtle forms of racism was still detected.

\section{Student 1}

One student remarked that during practice teaching, I felt out of place as a Life Orientation Religious education teacher. Firstly, I wasn't white and then I wasn't of the mainstream 
(Christian) religion. Racism very silent and subtle. Although there were no boards indicating which race is supposedly sitting where? In the school you feel that you are stepping into their territory and you must know your place. The feeling you get is that you must step back and know your place. It is not said explicitly.

When I explained to my mentor teacher why I was late during the 'train boycott' - she exclaimed as a Christian religious educator she will never go to that area let alone teach there.

Student 2

A young high school learner in my Life Orientation Religious education class blatantly told me - You inadequate because you a coloured - you can't teach me anything.

Jansen (2009) argues, that many young white South Africans hold rather similar views to those of their parents. It is not obvious and should not simply be assumed that younger white South Africans are significantly less racist than their predecessors

Student 3

As a Born Free Citizen of South Africa, I was never affected by the force of racism. I attended a pre-school that was mixed with different races as well as high and primary schools. The most effect Racism had on me were the stories I would slightly hear of my mother running from the police due to her skin colour or the protests meetings my grandmother attended. Being in a majority white area and attending a university with the majority being white students, it became clear to me the way in which racism seep into the next generation, the Born free Generation. Racism not explicit but very soft and subtle.

Thus, it was evident that some of the research projects and student teacher experiences were not without racial challenges. This became evident from the comments of students and from the feedback I received particularly from amongst a few students of colour in the Bachelor of Education programme.

Finally, there were also some general comments that serve as good advice for future preservice community engagement. Amongst the comments were the following:

- Some of the research projects were too over-ambitious; In their quest to be inclusive some PSTs became too involved in their centre and school visitations and wanted to tackle too many issues;

- Time constraints, as some of the projects seemed too extensive.

The need for more time to complete the project that included a visit to a religious centre, a report and a class presentation was also emphasised in some group discussions, which prompted the idea that the project needed to be smaller and more manageable. Another limitation of the project was that the pre-service teachers involved were at different levels of the deeper understanding other religions. It was evident in some of their projects that some students had no grasp, or only a very limited understanding, of what multicultural and multireligious research entails, as they lacked criticality. This could be because of a lack of confidence to express their opinions or viewpoints, and to explore alternative interpretations, 
or an inability to critically re-imagine or reflect more deeply. Some pre-service teachers clearly indicated in their discussions that they don't see the need to understand other religions and cultures, as they were already preoccupied with their own. They also felt that it was not their duty to make learners sensitive to inclusivity or to respect other religions and cultures as this should be instilled at home. They were also not happy with the behaviour of students from the other universities during the RMF and FMF uprisings and some of them expounded that decolonisation is not a concern to them.

What became clear from the deliberations with the students and from my own reflections was that exposing pre-service teachers critically to other religious cultures develops and nurtures much needed social consciousness and social justice in future educators. According to some of the pre-service teachers, the religion education module changed not only the way they thought about or perceived the other cultures and practices they encountered, but most importantly their prejudices. Together the community of pre-service teachers, student assistants and I as teacher-educator found new ways in which to think about schools and schooling, that is, new ways in which to think about the work of teaching and learning, and about teaching in a rapidly changing heterogeneous South Africa.

Regarding decolonisation, what was also obvious, all students did not see decolonisation as an issue or important for building a better South Africa. It became clear that reminding and discussing issues regarding race and addressing our colonial past to the majority white middle class pre-service teachers was still a thorny issue. One needs to decolonise and promote social cohesion in a very discreet and soft manner if you really want to be inclusive. Overall, it contributed to bringing our diverse students and lecturer closer and this for me is a definite decolonisation moment. So yes, decolonisation is not only about breaking down but also building up.

\section{Implications for pre-service teacher education:}

For all of us, this research project was significant because it provided us with evidence that research projects, if done collaboratively and in a participatory way, can empower pre-service teachers by giving them the tools to become effective practitioner social justice researchers. I believe that this type of empowerment drawing on the whole theme of enhancing social justice and sharing and caring for each other gave the PST's some confidence about their future. Also, the project enhanced the students' multicultural experience and bridged the theory-practice divide in that we integrated the university classroom with the community cultural centres and schools. This was evident amongst most of the PST's responses. For example, the groups responded as follows:

Working in groups and sharing our experiences made us more conscious of other cultures and their way of thinking and behaving.

I would never have been so brave to just go and talk about sensitive religious issues on my own at that centre.

We have become much more critically aware of how others live and practice their beliefs. 
With respect to the significance of this research for pre-service education, analysing the final reports indicated to me that pre-service teachers are capable of selecting and carrying out projects beneficial to their future learners. Furthermore, they indicated the satisfaction in choosing an issue that was significant for them as well as the benefit they derived from the implementation and analysis of their project; they also indicated that they intend to actively research their own practice and maintain their constant awareness of being agents for social change and uplifting the disadvantaged and the underprivileged. This was especially satisfying to me, as most of the students came from privileged backgrounds. Most of all, the pre-service teachers felt empowered as active agents in their own professional development. Regarding racism and religious bias that some students experienced it seems that the reality of racism, xenophobia and comprehending and respecting the religion of others remains an ongoing challenge.

In conclusion, decolonising religion education requires a multifaceted approach of both the school, community and higher education. Preparing pre-service teachers for teaching is necessary but not the only condition for transforming the legacy of colonisation and racism that scars South African society. However, no matter how small, any effort made to address racism, xenophobia, white privilege or unfair institutional culture is a step closer to restoring the inequalities, inequities and the injustices perpetrated by an apartheid past initiated by colonialists who have their roots in West. This pre-service teacher's religious education project made all the stakeholders more conscious that decolonisation is not about being antiwhite or anti-west but about addressing the inequalities of the past and about acknowledging the existence of all human beings as having potential.

Thus, the protest actions by university students during 2015 and 2016 impacted on aspects of government and socio-political culture in South Africa. Although it did not expel the government of the day, it served notice of a powerful post-liberation generation that does not live a reality of liberation and rights. It brought us back to reality that the struggle continues and that issues of white privilege and whiteness must not go unchallenged. It also questions the role we playing as academics given the space at the university.

Finally, this paper is not meant to be closed or conclusive but generative. And though we have not broken out of the white frame, we at least see it for what it is. Neither perfect nor pure, decoloniality is rather an attitude that keeps subjects and collectives open to growth and corrections as well as an unfinished project.

\section{References:}

Banks, J.A. 2006. Race culture and education. The selected works of James A Banks. New York: Routledge.

Brooke, J.H. 2010. Darwin and religion: Correcting the caricatures. Science \& Education 19 (45), 391-405.

Césaire, Aimé.2000. Discourse on Colonialism. Translated by Joan Pinkham. New York: Monthly Review Press. 
Chidester, David. 2002. "Religion Education: Learning about Religion, Religions, and Religious Diversity," in Kader Asmal and Wilmot James, eds., Spirit of the Nation: Reflections on South Africa's Educational Ethos. Cape Town: New Africa Education, Human Sciences Research Council, and the Department of Education, 91-102.

Cross, M., Mngadi, R. and Rouhani, S. 2002. From policy to practice: Curriculum reform in South African Education, Comparative Education 38 (20). 171-187.

Dei, G. 2000. Rethinking the role of indigenous knowledges in the academy. International Journal of Inclusive Education 4(2): 111-132.

Department of Education. 2001. Education White Paper 6: Building an inclusive education and training system: Pretoria.

Denzin, N.K., and Lincoln Y.S. 2000. Handbook of Qualitative Research. London: Sage.

Eck, D. 2001. A new religious America. San Francisco, CA: HarperCollins.

Ely, M. 1999. Doing qualitative research: Circles within circles. London: Falmer Press.

Enslin, P. 1984. The role of fundamental pedagogics in the formulation of educational policy in South Africa. In P. Kallaway (ed.). Apartheid and education (pp.139-147). Johannesburg: Raven Press.

Fanon, Frantz 2004. The Wretched of the Earth. Translated by Richard Philcox. New York: Grove Press.

Gearon, L. 2014. The Paradigms of Contemporary Religious Education Journal for the Study of Religion 27,1 (2014) 52 - 81 ISSN 1011-7601

Gearon, L. 2014. On Holy Ground: The Theory and Practice of Religious Education. London: Routledge.

Greenstein, R. 1998. New policies and the challenges of budgetry constraints, EPU Quarterly Review of Education and Training in South Africa 4(4):1-17.

Guba, E., and Lincoln, Y.S. 2005. Paradigmatic controversies, contradictions, and emerging confluences. In N.K. Denzin and Y.S. Lincoln (Eds.), The Sage handbook of qualitative research (3rd ed., p. 191-215.). Thousand Oaks, CA: Sage.

Hall, B.L. and Tandon, R. 2017 'Decolonization of knowledge, epistemicide, participatory research and higher education'. Research for All, 1 (1), 6-19. DOI 10.18546/RFA.01.1.02.

Jansen, J. 2009. Knowledge in the Blood: Confronting Race and the Apartheid Past. Stanford: Stanford University Press.

Kilman C. 2007. One nation, many gods. Teaching Tolerance, 32, 38-49

Kwenda, Chirevo., Nokuzola Mndende, and Janet Stonier. 1997. African Religion and Culture Alive. Cape Town: Via Afrika 
Le Grange, L. 2016. Decolonising the university curriculum. South African Journal of Higher Education. 30(2), 1-12.

Macedo, D. 2000. 'Introduction.' Paolo Freire Pedagogy of the Oppressed. New York, USA \& London, UK: The Continuum International Publishing Group Ltd., p. 11-27.

Maldonado-Torres, Nelson. 2007. 'On the Coloniality of Being: Contributions to the Development of a Concept'. Cultural Studies 21 (2-3): 240 . doi: $10.1080 / 09502380601162548$.

Maldonado-Torres, Nelson. 2016.'Outline of Ten Theses on Coloniality and Decoloniality'. Fondation Frantz Fanon. http://frantzfanonfoundation fondationfrantzfanon.com/IMG/pdf/maldonado - torres_outline_of_ten_theses10.23.16_.pdf

Mamdani, Mahmood. 2017. 'Decolonising the Post-colonial University: T.B. Davie Memorial Lecture Cape Town, 22 August.

Mbembe, Achille. 2001. On the Postcolony. Berkeley: University of California Press.

Marty, M (2000). Education, religion and the common good. San Fransisco, C.A. Jossey-Bass.

Mignolo, Walter. 2011 The Darker Side of Western Modernity: Global Futures, Decolonial Options. Durham: Duke University Press,

Nolan, Albert. 2001. "The Role of Religious Consciousness and the Development of Values." Saamtrek: Values, Education, and Democracy in the Twenty-First Century (http://education.pwv.gov.za).

Oldendorf, S.B. and Green, C.R. 2005. Listening to teacher voices: Religion in schools in the rural South. Religion and Education, 32(2), 65-84

Prothero, S. 2007. Religious literacy: What every American needs to know - And doesn't. San Francisco, CA: HarperCollins.

Puskás, T. and Andersson, A. 2019. Keeping Education Non-Confessional While Teaching Children about Religion. Pages 382-399 | Published online: 17 Apr 2019.

Reimers, E. 2019. Secularism and religious traditions in non-confessional Swedish preschools: entanglements of religion and cultural heritage Pages 275-284 | Published online: 20 Jan 2019.

Riccardi, R. 2011. What a Wonderful World. New York: NY: Random House Inc.

Santos, Boaventura de Sousa. 2016. Epistemologies of the South: Justice Against Epistemicide. New York: Routledge.

Smith, L. 1999. Decolonising methodologies: Research and indigenous peoples. London: Zed Books.

Stonier, Janet, and Tracy Derrick. 1997. Sacred Places: A New Approach to Religion Education for South African Primary Schools. Cape Town: Juta. 
Stonier, Janet, Nokuzola Mndende, A. Rashied Omar, Saraswathi S. Pillay, and Azila Reisenberger. 1996. Festivals and Celebrations. Cape Town: Juta.

Sunday Times: 28 October 2001.

Whitehead, J., and J. McNiff. 2006. Action Research: Living Theory. SAGE, London. 